\title{
KESETARAAN GENDER DALAM BUDAYA SIBALIPARRI MASYARAKAT MANDAR
}

\author{
Abdul Latief', Siti Maryam², Muh. Yusuf ${ }^{3}$ \\ Prodi Pendidikan Pancasila dan Kewarganegaraan \\ Universitas Al Asyariah Mandar \\ e-mail: latief2002@gmail.com
}

\begin{abstract}
Gender is a sex differences based on culture, where men and women are distinguished according to their respective roles that are constructed by local culture related to the role of nature, position and status in society. In the gender concept, the difference between men and women based on social and cultural construction of the mandar community has work behavior or culture that they are familiar with sibaliparri. Theresearch problemof this study is whether the culture of sibaliparri in which there is a gender equality. The motive of this research is to reveal how gender equality between a couple husband and wife in mandar community household based on sibaliparri cultural values. To find the answer of the research problem, a qualitative descriptive study is needed. Data collection methods used was field observations, interviews and literature study. The results showed that gender equality in mandar society was manifested in sibaliparri culture, namely the existence of mutual assistance between husband and wife and involving all family members.
\end{abstract}

Keywords: gender, sibaliparri, mandar society

\section{PENDAHULUAN}

Secara etimologi, kata gender berasal dari bahasa Inggris gender, yang berarti “jenis kelamin. Pengertian secara etimologis ini lebih menekankan hubungan antara laki-laki dan perempuan secara anatomis. Dalam Webster's New World Dictionary, kata gender diartikan sebagai perbedaan yang tampak antara laki-laki dan perempuan dilihat dari segi nilai dan tingkah laku. Disisi lain gender juga dapat dijelaskan sebagi konstruksi social yang mengantar pada pembagian peran social menurut jenis kelamin.

Gender adalah suatu konsep yang digunakan untuk mengindetifikasi perbedaan laki-laki dan perempuan dilihat dari segi pengaruh social budaya. Gender dalam pengertian ini ditilik sebagai bentuk rekayasa masyarakat yang tidaklah bersifat kodrati. Dimana gender perbedaan social antara laki-laki dan perempuan yang berubah bersama waktu dan mempunyai variasi luas dalam dan 

p-ISSN: 2087-3476 | e-ISSN: 2541-5700

antar budaya, di bedakan dari perbedaan biologis yang dipandang tetap dan dan tidak mengalami perubahan. (Muh. Idham Khalid, 2016)

Perempuan, dengan berdasarkan pada mitos-mitos yang ada, dianggap sebagai orang yang lemah dan perlu dilindungi oleh laki-laki yang kuat. Mereka lebih dianggap sebagai korban yang bergantung kepada laki-laki, daripada dianggap sebagai pribadi mandiri yang dapat mempertahankan dirinya sendiri. Anggota militer memberikan sebuah kehormatan khusus kepada perempuan sebagai orang yang harus dilindungi karena merupakan lambang feminitas dan keibuaan.

Gender merupakan perbedaan perilaku antara laki-laki dan perempuan yang dikonstruksi secara sosial, yakni perbedaan yang diciptakan oleh manusia (bukan kodrat) melalui proses sosial dan kultural yang panjang. Dalam Women's Studies Encyclopedia dijelaskan bahwa gender adalah suatu konsep kultural yang berupaya membuat pembedaan dalam hal peran, perilaku, mentalitas, dan karakteristik antara laki-laki dan perempuan yang berkembang dalam masyarakat.

Dengan demikian, secara umum dapat dikatakan bahwa gender dapat dikatakan tidak berlaku universal. Artinya setiap masyarakat pada waktu tertentu, memiliki sistem kebudayaan (cultural systems) tertentu yang berbeda dengan masyarakat lain dan waktu yang lain pula. Dalam system kebudayaan ini mencakup elemen deskriptif dan preskriptif, yaitu mempunyai citra yang jelas tentang bagaimana sebenarnya dan seharusnya laki-laki dan perempuan itu. (Siti Muslikhati, 2004)

Walaupun demikian, menurut hasil penelitian William, yang dilakukan pada tiga puluh negara menampilkan sebuah konsensus tentang atribut laki-laki dan perempuan. Dari hasil penelitian tersebut dapat diperoleh bukti bahwa sekalipun gender tidak universal, tetapi telah terjadi generalisasi kultural. Biasanya label maskulin dilekatkan pada laki-laki yang dianggap lebih kuat, lebih aktif, dan ditandai dengan kebutuhan yang besar terhadap pencapaian dominasi, otonomi dan agresi. Sebaliknya, label feminine identik dengan perempuan yang dipandang makhluk yang lebih lemah daripada laki-laki, kurang aktif, dan lebih punya kecenderungan mengalah. Dengan demikian gender menyangkut aturan sosial yang berkaitan dengan jenis kelamin manusia laki-laki dan perempuan.

Perbedaan biologis dalam hal alat reproduksi antara laki-laki dan perempuan memang membawa konsekuensi fungsi reproduksi yang berbeda (perempuan mengalami menstruasi, hamil, melahirkan dan menyusui laki-laki membuahi dengan spermatozoa). Jenis kelamin biologis inilah merupakan ciptaan Tuhan, bersifat kodrat, tidak dapat berubah, tidak dapat dipertukarkan dan berlaku sepanjang zaman.Namun demikian, kebudayaan yang dimotori oleh budaya patriarki menafsirkan perbedaan biologis ini menjadi indikator 
kepantasan dalam berperilaku yang akhirnya berujung pada pembatasan hak, akses, partisipasi, kontrol dan menikmati manfaat dari sumberdaya dan informasi.

Pemahaman mengenai gender pada hakekatnya adalah pemahaman yang pekat dengan nuansa barat. Kemudian diadopsi oleh Indonesia karena masyarakat Indonesia modern kurang memperhatikan esensi kebudayaan lokal mengenai dinamika relasi-relasi seksual. Gender sebagai suatu konsep bertumpu pada aspek biologis. Gender memiliki dua kategori biologis yang berbeda namun saling mengisi, yaitu pertama kategori laki-laki dan yang kedua adalah kategori perempuan. Setiap kategori mengandung makna yang pengertiannya bervariasi dari satu ke lain masyarakat. Setiap aktivitas, sikap, tata nilai dan simbol-simbol diberi makna oleh masyarakat pendukungnya menurutkategori biologis masingmasing.

Seks adalah pembagian jenis kelamin yang ditentukan secara biologis melekat pada jenis kelamin tertentu. Seks berarti perbedaan laki-laki dan perempuan sebagai makhluk yang secara kodrati memiliki fungsi-fungsi organisme yang berbeda. Dalam arti perbedaan jenis kelamin, seks mengandung pengertian laki-laki dan perempuan terpisah secara biologis, yang berarti perempuan memiliki hormon, postur tubuh dan alat reproduksi yang berbeda dengan lakilaki. Secara biologis alat-alat biologis tersebut melekat pada lelaki dan perempuan selamanya, fungsinya tidak dapat dipertukarkan, secara permanen tidak berubah dan merupakan ketentuan biologi atau kodrat. (Trisakti Handayani dan Sugiarti, 2006)

Sedangkan gender adalah sifat yang melekat pada kaum laki-laki dan perempuan yang dibentuk oleh faktor-faktor sosial maupun budaya, sehingga lahir anggapan tentang peran sosial dan budaya laki-laki dan perempuan. Bentukan sosial atas laki-laki dan perempuan itu antara lain : kalau perempuan dikenal sebagai makhluk yang lemah lembut, cantik, emosional atau keibuan. Sedangkan laki-laki dianggap kuat, rasional, jantan dan perkasa. Sifat-sifat itu dapat dipertukarkan dan berubah dari waktu ke waktu. Oleh karena itu dapat dikatakan bahwa gender dapat diartikan sebagai konsep sosial yang membedakan (memilih atau memisahkan) peran antara laki-laki dan perempuan. Perbedaan fungsi dan peran antara laki-laki dan perempuan itu tidak ditentukan karena antara keduanya terdapat perbedaan biologis atau kodrat, tetapi dibedakan atau dipilah-pilah menurut kedudukan, fungsi dan peranan masing-masing dalam berbagai bidang kehidupan dan pembangunan.

Perempuan tersubordinasi oleh faktor-faktor yang dikonstruksikan secara sosial. Banyak mitos dan kepercayaan yang menjadikan kedudukan perempuan berada lebih rendah daripada laki-laki. Hal itu semata-mata karena perempuan dipandang dari segi seks, bukan dari segi kemampuan, kesempatan dan aspekaspek manusiawi secara universal, yaitu sebagai manusia yang berakal, bernalar dan berperasaan. 
Melihat konsep kesetaraan gender bahwa adanya kondisi perempuan dan laki-laki menikmati status yang setara dan memiliki kondisi yang sama untuk mewujudkan secara penuh hak- hak asasi dan potensinya bagi pembangunan di segala bidang kehidupan. Definisi dari USAID menyebutkan bahwa "Gender Equality permits women and men equal enjoyment of human rights, socially valued goods, opportunities, resources and the benefits from development". Kesetaraan gender memberi kesempatan baik pada perempuan maupun laki- laki untuk secara setara menikmati hak-haknya sebagai manusia, secara sosial mempunyai benda-benda, kesempatan, sumberdaya dan menikmati manfaat dari hasil pembangunan. (Puspitawati, 2013)

Wujud kesetaraan dan keadilan gender dalam keluarga adalah: a) adanya akses yang bermakna bahwa kapasitas untuk menggunakan sumberdaya untuk sepenuhnya berpartisipasi secara aktif dan produktif (secara sosial, ekonomi dan politik) dalam masyarakat termasuk akses ke sumberdaya, pelayanan, tenaga kerja dan pekerjaan, informasi dan manfaat). Contoh: Memberi kesempatan yang sama bagi anak perempuan dan laki-laki untuk melanjutkan sekolah sesuai dengan minat dan kemampuannya, dengan asumsi sumberdaya keluarga mencukupi. b) Adanya Partisipasi. Partisipasi diartikan sebagai "Who does what? (Siapa melakukan apa?). Suami dan istri berpartisipasi yang sama dalam proses pengambilan keputusan atas penggunaan sumberdaya keluarga secara demokratis dan bila perlu melibatkan anak-anak baik laki-laki maupun perempuan. c) Adanya Kontrol. Kontrol diartikan sebagai "Who has what" (Siapa punya apa?). Perempuan dan laki-laki mempunyai kontrol yang sama dalam penggunaan sumberdaya keluarga. Suami dan istri dapat memiliki properti atas nama keluarga. d) Manfaat. Semua aktivitas keluarga harus mempunyai manfaat yang sama bagi seluruh anggota keluarga.

Pendidikan adil gender di tingkat keluarga sangatlah penting untuk membangun relasi gender yang lebih harmonis mulai dari tingkat keluarga sampai dengan tingkat nasional agar masyarakat adil dan makmur dapat tercapai dengan lebih cepat dan lebih baik. Melalui manajemen sumberdaya keluarga (yang terdiri atas sumberdaya materi, sumberdaya manusia, dan sumberdaya waktu) yang berwawasan gender, maka diharapkan masalah kemiskinan yang mendominasi masyarakat pesisir akan teratasi dengan lebih baik. Hal penting lain yang diharapkan berubah adalah adanya perubahan gradual terhadap belenggu budaya yang merugikan masyarakat pesisir baik laki-laki maupun perempuan dalam menuntut pendidikan formal di sekolah. Untuk itu, pengasuhan yang berwawasan gender adalah solusi yang tepat untuk meningkatkan angka partisipasi sekolah (APS) baik bagi laki-laki maupun perempuan.

Membahas tentang isu-isu yang bertalian dengan perempuan dan pemberdayaan, terdapat beberapa konsep yang perlu dijabarkan dalam batasannya. Untuk itu ada tiga konsep yang merupakan kunci, yaitu gender, 
mitra sejajar dan pemberdayaan. Isu gender akhir-akhir ini semakin ramai diperbincangkan apalagi mengenai kiprah wanita di sektor publik tidak akan pernah hilang. Hal ini karena momentumnya dianggp tepat mengadakan perubahan di segala bidang termasuk di dalamnya relasi gender.

Diharapkan dengan menggunakan konsep gender, penggambaran tersebut merujuk pada pemahaman bahwa identitas, peran, fungsi, pola prilaku, kegiatan serta persepsi tentang wanita dan pria bertumpu dalam kebudayaan dan bukan berdasarkan aspek biologis semata. Dan untuk itu bisa di awali dari proses sosialisasi yang dimulai dalam keluarga.

Lebih lanjut konsep kemitrasejajaran menyarankan, khusus untuk hal ini sebaiknya, di beri batasan sebagai kondisi di mana pria dan wanita memilki kesamaan hak dan kewajiban yang terwujud dalam kesempatan, kedudukan, peranan yang dilandasi sikap dan prilaku saling membantu dan saling mengisi dalam semua bidang kehidupan. Perwujudan kemitrasejajaran yang harmonis merupakan tanggung jawab bersama pria dan wanita. (Muh. Idham Khalid Bodi, 2016)

Begitu banyak kebudayaan yang memperlakukan laki-laki sebagai kaum yang dominan atas perempuan, hal ini tentunya bisa dipahami, sebab telah menjadi keniscayaan bahwa secara biologis perempuan mengalami menstruasi, mengandung, melahirkan, dan menyusui, kendati kenyataan setiap lingkungan dan ranah social budaya selalu berbeda reaksi dalam memperlakukan hukum alamiah ini sebagai keadaan biologis. Seakan beberapa pemerhati masalah perempuan seakan sepakat bahwa meskipun reaksi terhadap kondisi biologis perempuan berbeda-beda dan terpulang kepada latar belakang lingkungan social budaya yang dianut oleh masyarakat, namun secara umum perempuan diasosiasikan dengan sifat feminis sedangkan laki-laki dengan sifat dengan sifat maskulinitas. Diantara sifat feminis ialah sensitive, sabar, lembut, irasional serta lemah dan cenderung mengalah, hal ini biasanya dianggap melekat pada perempuan.

Adapun yang digolongkan sebagai sifat maskulinitas yang melekat pada laki-laki adalah keberanian, ketidaksabaran, agresif, sifat dominan, rasional dan kekuatan.khusus terhadap perempuan akses dari perbedaan tersebut mempengaruhi kepribadian dan prilaku yang dipunyai dan ditampilkan dalam memilih pekerjaan.

Pengembangan kepribadian dan prilaku serta pekerjaan yang khas bagi perempuan sesungguhnya diciptakan oleh proses sosialisasi, misalnya sejak dini perempuan telah diarahkan pada pembentukan sifat-sifat feminis melalui anjurananjuran dan pantangan yang berkenaan dengan boleh dan tidaknya melakukan suatu tindakan, atau pada saat pendistribusian peran dan tanggung jawab dimana perempuan tidak jarang hanya diarahkan kepada peran dan tanggung jawab 
untuk mengasuh anak, mengurusi dapur, dan urusan rumah tangga lainnya yang sifatnya adalah pekerjaan domestik.

Dasar dari pembagian peran ini diakibatkan oleh kehidupan keluarga yang lebih berdasarkan pada nilai-nilai tradisional, dengan pelabelan bahwa laki-laki adalah segalanya dan memiliki kecenderungan untuk selalu unggul dalam segala hal, sedangkan perempuan berada sebagai subordinat dari keunggulan laki-laki. Pembagian peran kerja berdasarkan pada seks (kelamin) ternyata ditolak banyak pakar dengan mendasarkan pada teori lingkungan. Bagi penganut teori ini, memang diakui bahwa terdapat perbedaan hakiki antara laki-laki dan perempuan, namun perbedaan tersebut tidaklah memberi kemungkinan bagi peran yang bersifat menetap yang merupakan fungsi dari sifat biologis, terdapat banyak dimana perempuan dapat berperan dalam jabatan yang sering diasosiasikan sebagai peran khas bagi laki-laki dan perempuan yang tampak hingga kini sesungguhnya bukanlah merupakan akibat dari warisan biologis, melainkan fungsi dari kondisi social budaya yang telah terstigmatisasi. (Jubariah, dkk, 2006)

Merebaknya kemiskinan antara lain adalah akibat dari minimnya sumberdaya dan tidak produktifitasnya kaum perempuan. Sehingga sangat urgen untuk menciptakan iklim kondusif bagi program yang diorientasikan pada peningkatan pendapatan bagi kaum perempuan. Sementara itu paham lain juga menyebutkan bahwa gagalnya program pembagunan ialah tidak dilibatkannya kaum perempuan. berpegang pada analisis terakhir ini, dibutuhkan upaya efisien dan efektif dalam membangun jalan untuk melibatkan perempuan keberbagai sektor yang diarahkan untuk menopang gerak langkah pembangunan.

\section{METODE PENELITIAN}

\section{Lokasi Penelitian}

Lokasi penelitian dilaksanakan di Desa Batulaya, Tinambung Polewali Mandar, dengan pertimbangan bahwa masyarakat di lokasi tersebut adalah mayoritas masyarakat mandar yang memegang teguh budaya dan prinsip Sibaliparri. Sehingga menjadi daya tarik tersendiri untuk peneliti mengetahui lebih dalam bagaimana budaya Sibaliparri dalam hubungannya dengan kesetaraan gender.

\section{Penentuan Informan}

Peniliti melakukan wawancara terhadap 15 orang masyarakat sebagai Informan, yang ditentukan secara purporsive sampling. Pemilihan informan didasarkan pada kebutuhan peneliti untuk mendapatkan data yang akurat. Olehnya itu informan adalah masyarakat yang masih memegang teguh dan menjalankan budaya Sibaliparri.

\section{Sumber Data}

a. Data primer; data yang diperoleh atau bersumber dari informan terutama data yang berasal dari hasil observasi wawancara 
b. Data sekunder; data yang diperoleh berdasarkan hubungan pembahasan dengan berbagai literature seperti kepustakaan.

\section{Metode Pengumpulan Data}

Pengumpulan data dilakukan dengan cara;

a. Observasi; yaitu mengadakan pengamatan langsung di lapangan untuk mengetahui keadaan objektivitas dilokasi penelitian. Dengan mengamati praktek kesetaraan gender pada budaya sibaliparri' dalam kehidupan masyarakat mandar.

b. Wawancara; dalam penelitian ini dilakukan tekhnik wawancara mendalam yang merupakan wawancara antara peneliti dengan beberapa informan yang bertujuan untuk memperoleh informasi. Dalam hal ini mengenai budaya sibaliparri'. Wawancara dilakukan dengan bertatap muka antara pewawancara dan informan dengan menggunakan pedoman wawancara.

c. Kajian Pustaka; yaitu mengumpulkan beberapa sumber buku dan jurnal yang relevan dengan fokus penelitian.

\section{Teknik Analisa Data}

Untuk menghasilkan dan menampilkan data yang akurat dan menarik. Maka dalam penelitian ini analisa data dilakukan dengan cara: reduksi data, penyajian data, dan penarikan kesimpulan. (Imam Gunawan, 2015)

\section{HASIL DAN PEMBAHASAN}

Pada bagian ini peneliti akan mengulas bagaimana konsep dan pemahaman masyarakat mandar terkait Sibaliparri, termasuk juga implementasinya di lokasi penelitian yaitu Desa Batulaya Kecamantan Tinambung Provinsi Sulawesi Barat.

Sibaliparri' adalah kegiatan saling bantu membantu antara suami dan istri serta anak-anak dalam lingkup keluarga, dimana antara suami dan istri samasama bekerja dalam mencari nafkah untuk kelangsungan kehidupan mereka dalam menopang kehidupan sehari-hari. Sebagai sebuah entitas, kebudayaan mandar khususnya di desa batulaya dilekati dan di bangun dari nilai-nilai yang dianut oleh masyarakat pendukungnya. Sehingga satu konsep nilai kebudayaan mandar yang gejalanya masih melekat hingga kini ialah konsep nilai kebudayaan mandar yang gejalanya masih melekat hingga kini ialah konsep sibaliparri'.

Konsep ini dapat dimaknai sebagai konsep kebersamaan, kegotongroyongan, atau sekaligus kesetaraan, diduga sibaliparri' berangkat dari konsep rumah tangga orang mandar, yakni pemahaman bahwa perempuan mandar, selain sangat setia, juga pandai menempatkan diri sebagai perempuan dan sebagai isteri. Pada dasarnya, dalam dunia rumah tangga, di pahami bahwa sibaliparri' adalah konsep yang mengharuskan perempuan atau istri untuk membantu kegiatan suami, sehingga dengan pemahaman ini, posisi istri dan suami dimata orang mandar tidak dipandang timpang atau berbeda, selain pegangan bahwa suami mutlak tampil sebagai pemimpin dan bertanggung jawab penuh atas 
kehidupan ekonomi keluarga. Namun demikian istri juga memiliki tanggung jawab yang setara atas kehidupan dan langgengnya bahtera rumah tangga, terutama nilai-nilai kehidupan dan beragama.

Hal ini senada dengan apa yang disampaikan oleh beberapa informan tentang budaya sibaliparri' tersebut.

Adapun informan pertama yang diwawancarai oleh peneliti dan atau tim peneliti yakni Muhammad Munir menyatakan bahwa tentang sibaliparri' tatarannya itu bukan hanya pada konteks keluarga namun meluas sampai tataran masyarakat. Proses sibaliparri' sangat tercipta dimana "di battu ummandeang nandiang tia mauang lao piapi anu" (pada saat sampai waktu makan tidak ada yang saling menyuruh pergi memasak namun kesadaran masing-masing) dan apabila dalam suatu kapal "tikai puka,na nandiang ma,uang i'o anu ondongo, naung disasi" (tersangkut jaringnya tidak ada yang saling memerintahkan untuk loncat ke laut namun mereka langsung tanggap). Sebab orang dulu itu memiliki rasa keikhlasan. Kata sibaliparri' diterjemahkan langsung oleh masyarakat tanpa ada tata tertib atau suatu aturan yang mengatur sebab masyarakat mandar merasa memilikinya.

Kemudian dalam konteks rumah tangga “ia tu'u di'o posasi'o ma'bulabulangi tu'u lamba" (nelayan itu biasanya pergi berbulan-bulan) dan banyak diantara mereka yang tidak menitipkan uang pada istrinya. Istrinya dirumah jika dia punya anak tentu mereka berpikir bagaimana cara menghidupi keluarganya maka disitulah letak sibaliparri', Dari proses inilah sehingga sang istri membuat sebuah kreatifitas dan wanita-wanita tangguh yang ada dimandar tidak pernah berpikir untuk mencari pengganti suami. Itulah kehebatan perempuan mandar dan konsep sibaliparri'. Agak berbeda dengan yang banyak kita jumpai misalnya sudah banyak perempuan yang bekerja di kantoran sehingga nilai juangnya sudah tidak terlalu melekat lagi dan sangat berbeda dengan keluarga yang profesinya sebagai nelayan dan petani.

Budaya sibaliparri' bisa juga kita liat dalam konteks yang berbeda, misalnya dalam hal gotong royong atau "diang mappake,de boyang" (ada yang mendirikan rumah). Sesungguhnya dulu itu hanya memamfaatkan pengeras suara Masjid untuk mengumumkan jika ada yang mendirikan rumah maka masyarakat akan datang dengan sendiri. Tidak harus ada undangan atau pemberitahuan secara formal. Kemudian selanjutnya bisa kita liat pada "panguma mattuda" (pekebun menanam) apa saja yang mereka tanam itu biasanya sistem kegotong royongan masih terasa misalnya "diang uma mesa hetto" (misalnya ada kebun satu hektar) masyarakat yang lain bisa membantu menanam begitupun sebaliknya jika masyarakat yang lain mau menanam.

Cuma semangat seperti ini juga mulai tergerus dan sudah mulai banyak yang hilang. Sehingga sangat perlu budaya sibaliparri' ini terus di tulis dan digaungkan karena mulai tergerus. Dalam hal ini menurut penuturan informan 
apabila kita tidak bisa menanamkan nilai-nilai tersebut dalam masyarakat dan keluarga, tentu untuk menjadi orang mandar di ragukan ke-Mandaran-nya, makanya sangat penting untuk terus kita sosialisasikan. Sebab nilai juang itu mulai hilang dan penanaman nilai tersebut harus di tanaamkan supaya generasi berikutnya punya spirit agar supaya "naissani parri"" (supaya dia terbiasa dengan kesusahan).

Hal senada juga sampaikan oleh Imma, ia mengatakan bahwa dalam kehidupan rumah tangga ada penerapan konsep kesetaraan gender dalam hal ini budaya sibaliparri' khususnya pada masyarakat yang berprofesi sebagai nelayan dan petani. Dalam penerapan budaya sibaliparri' saat ini seiring perkembangan zaman sedikit mengalami pergeseran. Orang-orang mandar dulu mayoritas aktifitas kesehariannya adalah masyarakat petani dan nelayan yang masih sangat kental dengan nilai-nilai sibaliparri' tersebut, misalnya nilai gotong royong, nilai keikhlasan dan nilai kerjasama.

Hal yang sama juga di sampaikan oleh Bapak Baharuddin, selaku kepala Dusun Layonga Galung salah satu dusun yang ada ada desa Batulaya, beliau mengatakan bahwa sibaliparri' adalah kebudayaan yang ada di Mandar, yaitu kesepakatan bersama dalam mencari nafkah antara suami dan istri. Informan menuturkan bahwa istrinya kalau pagi kerjanya mengajar (guru) dan beliau sendiri kerjanya di kebun. Sedangkan dalam kehidupan bermasyarakat Sibaliparri' itu tercermin dalam aktifitas gotong royong".

Hal yang sama di sampaikan oleh informan yakni Maslina, ia mengungkapkan bahwa sibaliparri' adalah dimana suami dan istri saling bantu membantu misalanya dalam keluarga saya, suami bekerja sebagai penjual parang dan saya sebagai tukang jahit dirumah sambil menjaga anak yang masih kecil, dan kadang membantu suami di kebun pergi mabayai roppong (membersihkan rumput)

Hal yang sama juga di sampaikan oleh Yahya, dimana dia mengatakan bahwa sibaliparri' adalah budaya saling membantu antara suami dan istri dalam mencari nafkah umtuk menunjang kelangsungan hidup berumah tangga".

Hal yang tak jauh berbeda dalam keluarga Syarimuddin, dimana latar belakang keluarganya adalah sama-sama Aparatur Sipil Negara (ASN). Kami kalau pagi-pagi sama-sama bekerja sebagai seorang pengajar dan yang terkadang menjaga anak kami dirumah adalah mertua saya atau orang tua dari istri karena kebetulan saya tinggal bersama mertua "ujarnya".

Hal yang tak jauh bebeda di sampaikan oleh pak Ridwan, ia mengatakan bahwa Sibaliparri' kalau di bahasakan adalah kerja sama, gotong royong dan merupakan budaya yang sangat bagus. Dalam agama juga di anjurkan. Dalam berbangsa dan bernegara terdapat kerja sama antar beberapa individu.

Hal yang tak jauh berbeda di sampaikan oleh Amir, bahwa Sibaliparri' artinya saling membantu dalam konteks masyarakat dan keluarga. Dalam konteks 
masyarakat ada kerja bakti. Dalam keluarga walaupun menurut agama laki-laki yang harus menafkahi keluarganya tapi bukan berarti sibaliparri' itu harus saling menghasilkan satu sama lain.

Hal yang tak jauh berbeda dengan apa yang disampaikan oleh Kaisar bahwa Sibaliparri' itu da,dua model nabawa (membawa dua model pengertian) dalam masyarakat ada kerja sama antara pemerintah setempat dan masyarakat. Dalam lingkup masyarakat saling membantu untuk kelangsungan hidup, salah satu contoh pappake'de boyang (mendirikan rumah). Sibaliparri' dalam keluarga saling membantu sanging me'uya mi tau kalau ada kemampuan (sama-sama bekerja sesuai dengan kemampuan). Informan menuturkan bahwa selain sebagai tenaga pengajar di salah satu kampus, juga mengharapkan hasil kebun miliknya yang digarap orang lain. Ada bagi hasil dengan penggarap. Istri bekerja sebagai pengerajin.

Informan selanjutnya yaitu Bambang Kuba mengatakan bahwa Ia di'o sibaliparri' istilana masussa siola toi tau masannang siola toi tau sipatiroi tau tangalalang macoa dilalanna pamboyangang datau ma'uang manyampai nasiolo'i rekeno siolai tau maparri siola toi tau manyamang (sibaliparri' itu saling pengertian dalam rumah tangga saling bahu-membahu dalam kesusahan). Sibaliparri' itu hanya berlaku dalam tataran rumah tangga. Informan juga melihat nilai-nilai Mandar sudah mulai tergerus oleh perkembangan zaman.

Dengan demikian, bagi masyarakat mandar baik dalam lingkup masyarakat terutama dalam lingkup keluarga antara suami dan istri dalam mencari nafkah ditemukan atau lahir dari sebuah latar pemahaman masyarakat yang betumpu pada konsep dan system nilai sibaliparri'. Namun demikian, selain dari aktifitas masyarakat yang bertani mereka juga memiliki banyak aktifitas lain seperti bekerja sebagai pengrajin, membuat tali, memelihara ternak seperti sapi, kambing dan ayam.

Peranan seorang wanita dimana selain sebagai ibu rumah tangga mereka pun membantu suami untuk menopang perekonomian keluarga tanpa mengabaikan peran utamanya sebagai pendidik pertama anak sebelum masuk usia sekolah . Hal ini sangat penting karena pembinaaan kepribadian anak dimulai sejak anak berada dalam kandungan, pendidikan pertama atau pembinaan utama bagi kepribadian anak adalah dari ibu. Pada tahun-tahun pertama dari proses pertumbuhan anak lebih banyak bersentuhan dengan ibunya. Pada lokasi penelitian ini antara laki-laki dan perempuan sama-sama bekerja keras sesuai dengan kondisi. Sama-sama pula menjaga dan mengurusi anak, serta kaitannya dengan urusan dapur. Sebab budaya sibaliparri' tersebut sudah tertanam kuat dalam jiwa masyarakat pada umumnya, sebagaimana pengertian sibaliparri' adalah sepenanggungan, kesejajaran, gotong royong, keikhlasan dan saling bantu membantu. 
Dalam kehidupan rumah tangga serta aktifitas masyarakat di kecamatan Tinambung tidak ada khusus pekerjaan wanita dan pekerjaan laki-laki, semua sama berdasarkan kemampuan masing-masing. Hal ini menunjukkan bahwa kesetaraan gender betul-betul tertanam dalam kebudayaan masyarakat pada konteks pembagian kerja.

Berdasarkan hasil wawancara yang dilakukan dari berbagai latar belakang keluarga informan, mulai dari keluarga petani, keluarga yang antara suami dan istri sama-sama aparatur sipil negara (asn), latar belakang keluarga yang ditinggal suaminya (janda), serta beberapa masyarakat setempat yang dijadikan sebagai informan. Pemahaman dan pandangan mereka tentang sibaliparri' adalah saling membantu satu sama lain.

Adapun beberapa hal yang jadi dasar penerapan sibaliparri' dalam kehidupan rumah tangga, salah satunya karena tuntutan ekonomi. Kondisi ekonomi yang dirasakan kurang mencukupi jika hanya suami yang bekerja. Maka dengan demikian istri pun ikut serta dalam mencari nafkah diluar rumah, tanpa mengurangi harkat dan martabat dari seorang suami sebagai kepala rumah tangga. Sebab hal demikian sudah menjadi kebiasaan bagi masyrakat mandar, terutama bagi keluarga yang aktifitas kesehariannya adalah petani begitupun dengan keluarga yang latar belakang janda atau hanya hidup bersama anaknya. Namun hal yang bebeda dari keluarga yang perekonomiannya mencukupi dalam hal ini aparatur sipil negara mereka menjalankan budaya sibaliparri' bukan karena tuntutan ekonomi melainkan tuntutan profesi, namun tetap dianggap melakukan sibaliparri'.

Sibaliparri' menjadi sebuah nilai yang menjadi dasar dalam membangun sebuah rumah tangga. Sebab para orang tua jika menasehati anaknya tentang pasangan hidup, maka mereka akan berkata bahwa carilah perempuan yang bisa kalian ajak untuk sibaliparri'. Bagi perempuan mandar aktifitas mengasuh anak dan melayani suami serta membantu menopang ekonomi keluarga adalah sebuah keharusan. Terlebih lagi bagi kalangan yang ekonominya pas-pasan, sebab salah satu pilihan yang tidak bisa ditawar-tawar sebelum mereka membina sebuah keluarga bersama suaminya ialah kesiapan untuk berperan ganda. Yakni, selain siap melayani suami dan mengasuh anak-anaknya kelak, para calon istri juga harus siap mental untuk turut berperan aktif dalam membantu suami memenuhi kebutuhan ekonomi keluarga dan rumah tangganya.

Meski beragam pekerjaan dan istilah, namun yang pasti dalam kehidupan sehari-hari mereka juga memahami dan menerapkan sibaliparri' baik itu dalam masyarakat maupun dalam lingkup keluarga sebagai sebuah keharusan dalam kehidupan mereka. Sebagai petani atau pekebun suami istri dapat saling berbagi peran dan tugas, misalnya suami menggarap atau mencangkul dan istri menanam. Selain itu, suami dan istri dapat juga melakukan hal yang sama dalam satu waktu. 
Adapun dikalangan peternak seorang istri dapat melakukan aktifitasnya sedangkan suaminya meladang.

Disamping bekerja sebagai petani dan beternak ada beberapa aktifitas lain yang seringkali di lakukan masayarakat ialah memintal tali. Nilai sibaliparri' sangat nyata yaitu pada pembagian peran yang melibatkan seluruh anggota keluarga termasuk anak dan mertua. Terlihat juga dalam lingkup keluarga yang latar belakang aparatur sipil negara (ASN), misalnya jika suami dan istri samasama pergi mengajar di sekolah maka yang mengurus anak di rumah ialah mertua sesuai dengan kesanggupan anggota rumah tangga yang bersangkutan.

Maka dari itu dalam masyarakat pada umumnya dan kuhususnya kecamatan tinambung hal demikian sudah menjadi hal yang biasa jika perempuan ikut serta bekerja di luar rumah tangga di samping mengurusi anak. Terjadi bukan karena adanya paksaan atau intimidasi dari suami namun mereka bekerja atas dasar keikhlasan agar kehidupan ekonomi mereka terpenuhi sehingga akan tercipta hubungan yang harmonis yamg dapat melanggengkan kehidupan rumah tangga mereka.

Berdasarkan hasil kajian lapangan dengan kegiatan observasi serta wawancara yang dilakukan oleh peneliti dan tim yang didukung oleh data dan dokumentasi, bahwa dalam masyarakat mandar kesetaraan gender itu ada tersimpul dalam kebudayaan sibaliparri'. Ada kesetaraan dan kesejajaran antara laki-laki dan perempuan dalam konteks pembagian kerja, sebab apa yang dilakukan oleh laki-laki dikerjakan pula oleh perempuan, misalnya biasanya lakilaki yang sering pergi mengambil makanan kambing tapi perempuan juga terkadang yang melakukannya. Terus biasanya istri yang mengurusi anak dirumah tapi laki-laki juga sering melakukannya. Hal demikian tidak terlepas dari nilai-nilai religious masyarakat Mandar yang mayoritas muslim. Sumber ajarannya dari Al-Qur'an, sebagaimana dalam surah Al-Hujarat; "Hai sekalian manusia telah kuciptakan kalian berbangsa-bangsa dan bersuku-suku supaya kalian mengenal satu sama lain, dan orang yang paling mulia disisi Allah Swt. adalah orang orang-orang yang bertakwa. Hal demikianlah yang di terapkan oleh para perempuan bahwa membantu suami dalam mencari nafkah adalah salah bentuk ketakwaan.

Fenomena sibaliparri' yang telah di amati secara empiris dalam rumah tangga masyarakat mandar, antara lain pada kegiatan manette lipa sa'be mandar atau bertenun sarung sutra mandar. Kegiatan kreatifitas perempuan inilah yang salah satunya dimaksudkan dapat membantu perekonomian keluarga. Adapun prinsip yang mendasari konsep sibaliparri' ialah pemahaman masyarakat bahwa laki-laki dan perempuan itu sama dan tidak perlu di beda-bedakan antara keduanya, karena laki-laki dan perempuan adalah sama-sama ciptaan sang maha pencipta. Selain itu dalam diri anak terdapat paduan dua sifat dari ayah dan ibu saat pembuahan. 
Dalam praktiknya, hal itu termanifestasi ke dalam anutan nilai-nilai humanisasi yang melekat pada diri setiap manusia. Sebagai entitas kebudayaan, hal yang sama terjadi dalam masyarakat mandar pada umumnya dan khususnya masyarakat kecamatan Tinambung. Terkait dengan nilai humanitas itulah sehingga dalam komunitas masyarakat mengakar sebuah pola interaksi yang disebut sibaliparri' sebagai konsep humanitas yang terkristalisasi dan merasuk secara sentripugal kedalam kehidupan masyarakat. Dianut dan dipertahankannya sibaliparri' sampai saat ini telah menjadikan konsep kebudayaan tersebut sebagai nilai budaya yang turun temurun di pelihara dan ditumbuh kembangkan oleh masyarakat.

Kendati demikian, sibaliparri' bagi orang mandar, adalah pengungkapan jati diri sebagai pribadi dan kelompok yang memegang teguh pesan leluhur (pappasang todiolo'). Seperti diketahui, para leluhur mandar selalu mengedepankan persaudaraan yang dikenal dengan istilah palluluareang.

Makna palluluareang ialah bahwa orang mandar itu bersaudara, sejatinya masyarakat mandar adalah pribadi yang senantiasa mengedepankan persaudaraan kepada siapapun tanpa mengenal starata sosial. Prilaku sibaliparri' akan selalu eksis karena di samping sebagai bentuk kerja sama yang ada dalam setiap kelompok masyarakat, ia juga sangat terkait dengan kepribadian orangorang mandar dan hal tersebut tercermin dalam falsafah hidup yang menyebutkan bahwa "sisara'pai mata mapute anna' mata malotong anna' sisara' palluluareang".

Dari falsafah tersebut dapat dipahami bahwa sibaliparri' ditopang oleh kesadaran akan eksistensi sebagai manusia yang harus berusaha bagaimana menjadi manusia yang bermamfaat, sehingga bukti kepedulian akan terus diwujudkan baik dalam keluarga maupun masyarakat dalam bentuk kesediaan memberikan bantuan moril maupun materil bahkan spiritual.

\section{SIMPULAN}

Bagi masyarakat Mandar terlihat dengan jelas bahwa kesetaraan gender itu termanifestasi dalam kebudayaan sibaliparri'. Suami dan istri sama-sama punya ruang dan akses untuk bekerja diluar rumah tanpa ada batasan ataupun tata tertib yang mengatur dan melarang. Bahkan anak serta mertua ikut serta membantu menopang perekonomian keluarga untuk kelangsungan kehidupan rumah tangga yang dapat menambah rajutan harmonisasi. Sibaliparri' dalam masyarakat mandar telah menjadi budaya yang mengakar dan diwariskan secara turun temurun oleh orang-orang terdahulu. Budaya ini masih eksis sampai sekarang dan mampu beradaptasi dengan perkembangan zaman. Bahkan sibaliparri' tersebut telah menjadi identitas dan pengungkapan jati diri masyarakat Mandar. Selain daripada itu konsep sibaliparri' ataupun kesetaraan gender ini tidak terlepas dari nilai-nilai religius. Menariknya sibaliparri' termanifestasi bukan hanya pada ranah keluarga namun hal demikian juga 
berlaku dalam ranah sosial kemasyarakatan seperti halnya saling bantumembantu antar warga masyarakat.

\section{SARAN}

Adapun saran terkait dengan hasil penelitian ini bahwa budaya sibaliparri mesti terus dilestarikan dan dijaga agar tetap mengakar dan membumi dalam masyarakat. Penelitian dan studi terhadap kearifan-kearifan lokal perlu tetap dilakukan untuk terus menemukan dan mengangkat nilai-nilai lokal yang dapat memberi sumbangsih pengetahuan untuk pembangunan dan mewujudkan masyarakat yang paham akan jati dirinya, terimplementasi dalam kehidupan sehari-hari.

\section{DAFTAR PUSTAKA}

Ansar. 2013 Aktualisasi Nilai-nilai Budaya Lokal Pada Perkawinan Adat Mandar.

Makassar:De La Macca,.Silam.Cet 1 ujung pandang

Asruddin, 2014. Implementasi Nilai-Nilai Sibaliparri dalam Manajemen

Pembiayaan Sekolah. Jurnal Eklektika, Vol. 2 Nomor 1, April 2014

Bodi Muh. Idham Khalid. 2016, Sibaliparri'; Gender Masyarakat Mandar. Kauman, Solo: Zadahaniva Publishing

Chuduriah Sahabuddin. 2013, Panette, Sebuah Sistem Sibaliparri dalam Keluarga Mandar: Jurnal Pepatudzu, Vol.5 Nomor 1, Mei 2013

Hadi, Sutrisno. 2002. Metodolgi Research. Jogjakarta. Fakultas Psikologi UGM

Handayani, Trisakti dan Sugiarti 2006, Konsep dan Teknik Penelitian Gender, Edisi Revisi, Cetakan Kedua, UMM Press, Malang

Imam Gunawan 2015, Metode Penelitian Kualitatif Teori dan Praktik. Cet.3 Jakarta: Bumi Aksara

Jubariah Dkk, 2006. Sibaliparri Dalam Perspektif Pemberdayaan Perempuan. Balaniva Publishing Yogyakarta, Beranda Cendekia Konsultan, Mammesa Art Community.

Siti Muslikhati 2004, Feminisme dan Pemberdayaan Perempuan dalam Timbangan Islam, Jakarta: Gema Ihsani Press.

Puspitawati, H. 2012. Gender dan Keluarga: Konsep dan Realita di Indonesia. Bogor: PT IPB Press, hal.6 